\title{
Case series of the first three severe COVID-19 patients treated with the secretome of hypoxia-mesenchymal stem cells in
}

\section{Indonesia [version 1; peer review: 1 approved, 1 approved}

\section{with reservations]}

\author{
Agung Putra (iD1-3, Agus Widyatmoko4, Sugeng Ibrahim¹,5, Fajar Amansyah6, \\ Farid Amansyah6, Mukti Arja Berlian7, Retnaningsih Retnaningsih(iD8, \\ Zenitalia Pasongka9 ${ }^{9}$ Flora Eka Sari10, Basuki Rachmad ${ }^{11}$

\footnotetext{
${ }^{1}$ Stem Cell and Cancer Research (SCCR), Faculty of Medicine, Universitas Islam Sultan Agung (Unissula), Semarang, Central Java, Indonesia

${ }^{2}$ Department of Postgraduate Biomedical Science, Faculty of Medicine, Universitas Islam Sultan Agung (Unissula), Semarang, Central Java, Indonesia

${ }^{3}$ Department of Pathological Anatomy, Faculty of Medicine,, Universitas Islam Sultan Agung (Unissula), Semarang, Central Java, Indonesia

${ }^{4}$ Department of Internal Medicine, Faculty of Medicine, Universitas Muhammadiyah Yogyakarta, Yogyakarta, Yogyakarta, Indonesia ${ }^{5}$ Department of Molecular Biology, Faculty of Medicine, Universitas Katholik (Unika) Soegijapranata, Semarang, Central Java, Indonesia

${ }^{6}$ Department of Internal Medicine, Bhayangkara Hospital, Makassar, South Sulawesi, Indonesia

${ }^{7}$ Department of Internal Medicine, Dr. Esnawan Antariksa Air Force Hospital, Jakarta, Jakarta, Indonesia

${ }^{8}$ Department of Neurology and Intensive Care Unit, Kariadi Hospital, Universitas Diponegoro, Semarang, Central Java, Indonesia

${ }^{9}$ Faculty of Medicine, Universitas Udayana, Denpasar, Bali, Indonesia

${ }^{10}$ Department of Pulmonary Medicine, Dr. Esnawan Antariksa Air Force Hospital, Jakarta, Jakarta, Indonesia

${ }^{11}$ Department of Intensive Care Unit, Gatot Soebroto Army Hospital, Jakarta, Jakarta, Indonesia
}

V1 First published: 22 Mar 2021, 10:228

https://doi.org/10.12688/f1000research.51191.1

Second version: 22 Jul 2021, 10:228

https://doi.org/10.12688/f1000research.51191.2

Latest published: 22 Oct 2021, 10:228

https://doi.org/10.12688/f1000research.51191.3

\section{Abstract}

Severe acute respiratory syndrome coronavirus 2 (SARS-CoV-2) is responsible for the outbreak of coronavirus disease 2019 (COVID-19), which has been rapidly spreading. Several guideline therapies have been proposed as a possible treatment for SARS-CoV-2, however, these therapies are not sufficient to treat a severe condition of SARSCoV-2 infection characterised by the increase of D-dimer and Creactive protein (CRP) levels, and patchy ground-glass opacities (GGOs). Secretome-mesenchymal stem cells (S-MSCs) produced by MSCs under hypoxia could excessively release several antiinflammatory cytokines and growth factors to control the COVID-19 cytokine storm and accelerate lung injury improvement. This is the

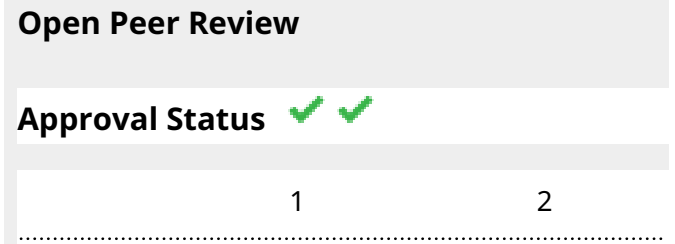

version 3

(revision)

22 Oct 2021

version 2

(revision)

22 Jul 2021

version 1

22 Mar 2021
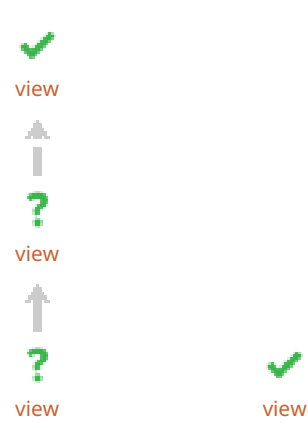
first study investigating the clinical outcomes of three severe COVID19 patients admitted to the intensive care unit of three different hospitals in Indonesia treated with S-MSCS. The decrease of D-dimer and CRP level was reported for all patients treated with S-MSCs. This was in line with improvement of pulmonary radiology, blood gas level, and hematologic assessment. In conclusion, these cases suggest that S-MSCs could effectively control D-dimer, CRP level and GGOs of severe COVID-19 patients associated with recovered pulmonary function.

Keywords

COVID-19, secretome, mesenchymal stem cells

\section{Rajesh Ramasamy ID, Universiti Putra}

Malaysia, Selangor, Malaysia

2. Guido Moll (D), Berlin Institute of Health,

Charité - University Medicine Berlin, Berlin, Germany

Any reports and responses or comments on the article can be found at the end of the article.

This article is included in the Emerging Diseases and Outbreaks gateway.

collection.

Corresponding author: Agung Putra (dr.agungptr@gmail.com)

Author roles: Putra A: Conceptualization, Validation, Writing - Review \& Editing; Widyatmoko A: Conceptualization, Data Curation, Investigation; Ibrahim S: Formal Analysis, Resources; Amansyah F: Methodology, Resources, Visualization; Amansyah F:

Conceptualization, Data Curation, Resources; Berlian MA: Conceptualization, Resources, Supervision; Retnaningsih R: Formal Analysis, Visualization; Pasongka Z: Investigation, Project Administration; Sari FE: Writing - Original Draft Preparation; Rachmad B: Resources, Writing - Original Draft Preparation

Competing interests: No competing interests were disclosed.

Grant information: This study was funded by the Provincial Government of Central Java, Indonesia.

The funders had no role in study design, data collection and analysis, decision to publish, or preparation of the manuscript.

Copyright: $\odot 2021$ Putra A et al. This is an open access article distributed under the terms of the Creative Commons Attribution License, which permits unrestricted use, distribution, and reproduction in any medium, provided the original work is properly cited.

How to cite this article: Putra A, Widyatmoko A, Ibrahim S et al. Case series of the first three severe CoviD-19 patients treated with the secretome of hypoxia-mesenchymal stem cells in Indonesia [version 1; peer review: 1 approved, 1 approved with reservations] F1000Research 2021, 10:228 https://doi.org/10.12688/f1000 research.51191.1

First published: 22 Mar 2021, 10:228 https://doi.org/10.12688/f1000research.51191.1 


\section{Introduction}

Since December 2019, severe acute respiratory syndrome corona virus 2 (SARS-CoV-2), responsible for the outbreak of coronavirus disease 2019 (COVID-19), has been rapidly spreading worldwide ${ }^{1}$. The number of infected persons has exceeded 87 million with 2 million deaths globally ${ }^{2}$. Several guideline therapies such as remdesivir and convalescent plasma have been proposed as possible treatment for SARS-CoV-2, however these treatments remain controversial. Moreover, these therapies were not effective to treat severe infection of SARS-CoV-2 due to these treatments potentially inducing the robust cytokine storm $^{3,4}$. A previous study demonstrated that there is a correlation between disease severity and the release of proinflammatory cytokines, such as tumor necrosis factor- $\alpha$ (TNF- $\alpha$ ), IL-6, IL-1B, IL-4, IFN- $\gamma$, IFN- $\gamma$-induced protein 10 (IP10), monocyte chemoattractant protein-1 (MCP-1), macrophage inflammatory protein-1a (MIP-1a), and granulocyte-colony stimulating factor $(\mathrm{G}-\mathrm{CSF})^{5}$. This finding was confirmed by the high plasma cytokines found in the most severe COVID-19 patients associated with extensive lung damage ${ }^{6,7}$. Therefore, finding an effective therapeutic option to hamper the devastating cytokine storm of COVID-19 and regenerate the damaged lung is crucial. Previous studies recently reported several benefits of mesenchymal stem cells (MSCs) under hypoxia condition to inhibit robust proinflammatory cytokines and repair extensive tissue damage by releasing several anti-inflammatory cytokines and growth factors ${ }^{8}$.

The use of hypoxia-MSCs (H-MSCs) could become an alternative solution to treat the severe cytokine storm of COVID-19. A previous study reported that hypoxia precondition treated on MSCs (H-MSCs) could enhance their survival to reach the damaged area'. However, blood clots appearing during the severe phase of COVID-19 could block the H-MSCs' trajectory into the damaged $\operatorname{are}^{10}$. Other studies reported that H-MSCs could enhance the release of their active soluble molecules, known as secretome-MSCs (S-MSCs) such as IL-10, TGF beta, VEGF and PDGF, which are useful in hampering inflammation and improving tissue healing ${ }^{11}$. Therefore, isolating and concentrating the exact active soluble molecule of S-MSCs is a possible strategy to control the cytokine storm of COVID-19, and, in addition, to accelerate the damaged lung improvement.
In a recent study, we successfully isolate S-MSCs from their culture medium using tangential flow filtration (TFF) strategy with several molecular weight cut-off category ${ }^{12}$. In this Clinical Practice article, we report on three severe COVID-19 patients with several comorbidities who were treated with S-MSCs in three different hospitals in Indonesia. This is the first report to describe the complete monitoring of these three patients.

\section{Ethical considerations}

Ethical clearance for the use of S-MSCs in COVID-19 cases and the protocol for administration was obtained from the Health Research Ethics Committee of Bethesda Hospital, Yogyakarta, Indonesia (approval number, No.91/KEPK-RSB/VI/20). Written informed consent for treatment with S-MSCs was obtained from each patient prior to treatment. All patients were treated with standard treatments for severe condition of COVID-19 infection, in addition to novel S-MSCs therapy regarding. Each patient was treated with three, four and six doses of $1 \mathrm{~mL}$ S-MSCs every $12 \mathrm{~h}$ (with molecular weight cut-off combination of $10-50 \mathrm{kDa} 50 \%, 50-100 \mathrm{kDa} 25 \%$, and $100-300 \mathrm{kDa} 25 \%$ ) via deltoid intramuscular injection, respectively. A different S-MSCs dose was utilized in the three patients due to the preliminary nature of this treatment.

\section{Case reports}

Case no. 1

A 54-year-old Indonesian male with severe hypertension was diagnosed with COVID-19 on August 28, 2020 and admitted to Dr. Esnawan Antariksa Air Force Hospital, Jakarta, Indonesia intensive care unit (ICU) with cough and dyspnea (Table 1) and was treated with standard treatment (Table 2). The examination showed a temperature of $36^{\circ} \mathrm{C}$, a $102 /$ min pulse, a respiratory rate of $32 / \mathrm{min}$, and a blood pressure of 200/100. Blood gas analysis showed decreased oxyhemoglobin saturation (SO2, 80.6\%; normal reference: 95-100\%), $\mathrm{CO}_{2}$ partial pressure $\left(\mathrm{PCO}_{2}, 22.9 \mathrm{mmHg}\right.$; normal reference: $38-42 \mathrm{mmHg}$ ), oxygen partial pressure $\left(\mathrm{PO}_{2}\right.$, $37.6 \mathrm{mmHg}$; normal reference: $70-99 \mathrm{mmHg}$ ) and $\mathrm{HCO}_{3}$. (18.9 mmol/L; normal reference: $22-29 \mathrm{mmol} / \mathrm{L})$. Laboratory studies showed increased white blood cells $(\mathrm{WBC})$ count $(17.2 \times$ $10^{9} / \mathrm{L}$; normal reference: $\left.4-10 \times 10^{9} / \mathrm{L}\right)$, monocyte count $(9 \%$; normal reference: $2-8 \%$ ) and decreased lymphocyte count

\section{Table 1. Clinical characteristics of COVID-19 patients receiving S-MSCs.}

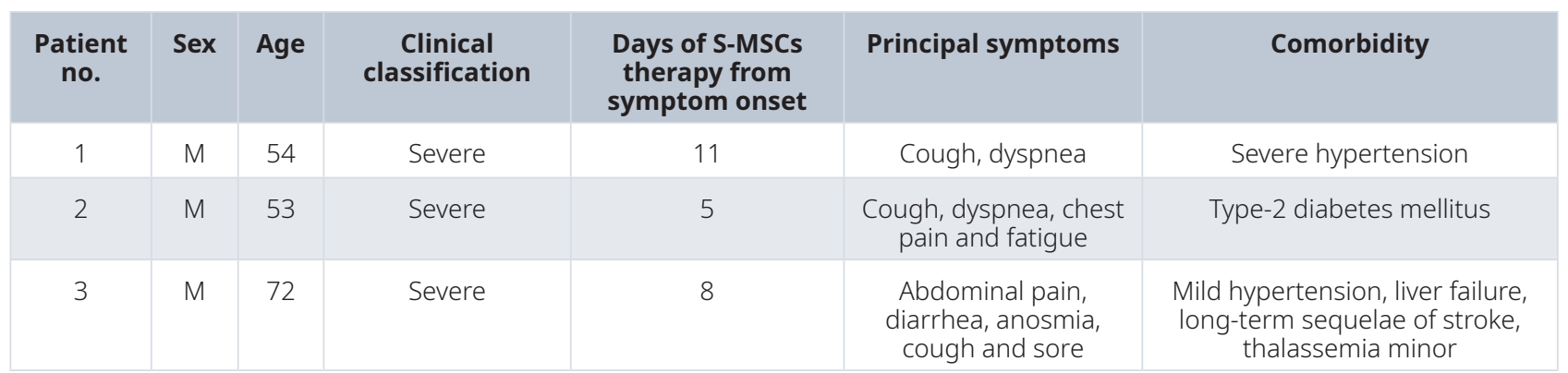


(15\%; normal reference: 20-40\%). On August 29, D-dimer was increased (1540 ng/mL; normal reference: 0-231 ng/mL) in line with the elevation of C-reactive protein $(\mathrm{CRP}, 61.7 \mathrm{mg} / \mathrm{dL}$; normal reference: $0-8.1 \mathrm{mg} / \mathrm{L}$ ) (Table 3). Chest X-ray showed bronchopneumonia with bilateral ground glass opacities (GGOs) and cardiomegaly condition (Figure 1).

The patient was treated with $1 \mathrm{~mL} \mathrm{S-MSCs} \mathrm{three} \mathrm{times} \mathrm{every}$ $12 \mathrm{~h}$ via deltoid intramuscular on August 30 and 31.

On September 4, $\mathrm{SO}_{2}$ was increased (99.6\%) with increased $\mathrm{PCO}_{2}$ (36.2 mmHg), $\mathrm{PO}_{2}$ (198.7 mmHg), and $\mathrm{HCO}_{3}^{-}(24.7 \mathrm{mmol} / \mathrm{L})$. Laboratory studies showed normal WBC count $\left(7.4 \times 10^{9} / \mathrm{L}\right)$, monocyte count (5\%) and lymphocyte count (20\%). D-dimer and CRP level were decreased (1297 ng/mL and $2.33 \mathrm{mg} / \mathrm{dL}$, respectively) (Table 3). The chest X-ray still showed a bronchopneumonia with cardiomegaly condition (Figure 1). On September 10, the patient was reported negative from COVID-19 infection. The chest X-ray showed improvement with no both bronchopneumonia and cardiomegaly observed. D-dimer was decreased (384 $\mathrm{ng} / \mathrm{mL})$, and CRP was normal (0.31 $\mathrm{mg} / \mathrm{dL})$. On 20 September, the patient has no cough and dyspnea. The examination showed that $\mathrm{SO}_{2}$ was $98.7 \%$. $\mathrm{He}$ was discharged from ICU and mobilized into rehabilitation room for standard recovery of physical activity.
Case no. 2

A 53-year-old Indonesian male with type 2 diabetes mellitus was diagnosed with COVID-19 on November 16, 2020. He was admitted to Gatot Soebroto Army Hospital, Jakarta, Indonesia on November 17 with cough, dyspnea, chest pain and fatigue (Table 1). On November 19, he was admitted to the ICU due to worsened dyspnea and treated with standard treatment (Table 2). Chest X-ray revealed cardiomegaly with lung edema, bilateral GGOs, aorta elongation and aorta atherosclerosis (Figure 2). Blood gas analysis showed $\mathrm{PCO}_{2}(29.9 \mathrm{mmHg}$ ), $\mathrm{PO}_{2}(177.1 \mathrm{mmHg})$ and $\mathrm{HCO}_{3}^{-}(20.8 \mathrm{mmol} / \mathrm{L})$, however $\mathrm{SO}_{2}$ was still normal (98\%). On November 21, the $\mathrm{SO}_{2}$ was $90.6 \%$ (abnormal) with reduced $\mathrm{PO}_{2}(57.5 \mathrm{mmHg})$. Laboratory studies showed normal WBC count $\left(6.02 \times 10^{9} / \mathrm{L}\right)$ with increased neutrophil count (81\%, normal reference: $50-70 \%)$, monocyte count $(9 \%)$ and decreased lymphocyte count (10\%). D-dimer was abnormal $(880 \mathrm{ng} / \mathrm{mL})$. Blood chemistries revealed elevations in CRP (160 mg/L) and fasting plasma glucose (FPG, 398 mg/dL; normal reference: 70-140 mg/dL (Table 3).

Due to the patient's worsening condition, he was injected with $1 \mathrm{~mL}$ S-MSCs four times every $12 \mathrm{~h}$ via deltoid intramuscular injection on November 21 and 22. On the same day, 6 hours after injection, $\mathrm{SO}_{2}$ increased $\left(98.7 \%\right.$ ) with increased $\mathrm{PO}_{2}$ (138.5 mmHg), $\mathrm{pH}(7.509)$ and $\mathrm{HCO}_{3}^{-}(29.7 \mathrm{mmol} / \mathrm{L})$. On November

\section{Table 2. Standard treatment received by the three patients receiving S-MSCs.}

\begin{tabular}{|c|c|c|c|c|c|}
\hline $\begin{array}{c}\text { Patient } \\
\text { no. }\end{array}$ & Antiviral treatment & $\begin{array}{c}\text { Drugs Administrated } \\
\text { Antibiotic or antifungal } \\
\text { treatment }\end{array}$ & $\begin{array}{c}\text { Corticosteroids } \\
\text { treatment }\end{array}$ & $\begin{array}{c}\text { Before S-MSCs } \\
\text { Therapy }\end{array}$ & $\begin{array}{c}\text { After S-MSCs } \\
\text { therapy }\end{array}$ \\
\hline 1 & $\begin{array}{c}\text { Remdesivir } 100 \mathrm{mg}, \\
\text { q24h i.v. in } 5 \text { days }\end{array}$ & $\begin{array}{c}\text { Azithromycin po. and } \\
\text { Levofloxacin i.v. }\end{array}$ & $\begin{array}{c}\text { Dexamethasone } \\
\text { i.v. }\end{array}$ & High-flow nasal oxygen & nasal cannula \\
\hline 2 & $\begin{array}{c}\text { Oseltamivir } 75 \mathrm{mg}, \\
\text { q12h po. in } 5 \text { days }\end{array}$ & Azithromycin po. Levofloxacin i.v. & None & High-flow nasal oxygen & nasal cannula \\
\hline 3 & $\begin{array}{c}\text { Favipiravir } 600 \mathrm{mg} \\
\text { q12h po. In } 5 \text { days }\end{array}$ & $\begin{array}{c}\text { Azithromycin po., Tazobactam } \\
\text { Sodium and Levofloxacin i.v. }\end{array}$ & $\begin{array}{c}\text { Dexamethasone } \\
\text { i.v. }\end{array}$ & High-flow nasal oxygen & nasal cannula \\
\hline
\end{tabular}

po., per os; i.v., i.v. injection; q12h, every 12 h; q24h, every 24 h.

Table 3. Comparison of laboratory parameters before and after S-MSCs treatment.

\begin{tabular}{|c|c|c|c|c|c|c|}
\hline \multirow[t]{2}{*}{ Clinical Factors } & \multicolumn{3}{|c|}{ Before S-MSCs treatment } & \multicolumn{3}{|c|}{ After S-MSCs treatment } \\
\hline & Patient 1 & Patient 2 & Patient 3 & Patient 1 & Patient 2 & Patient 3 \\
\hline CRP (mg/L, normal reference: 0-8.1 mg/L) & 61.7 & 160 & 118 & 0.37 & 5.12 & 8.5 \\
\hline D-dimer (ng/mL, normal reference: 0-231 ng/mL) & 1540 & 880 & 235 & 384 & 660 & 87 \\
\hline Lymphocyte (\%, normal reference: 20-40\%) & 15 & 10 & 11.7 & 20 & 27 & 25.8 \\
\hline $\mathrm{SO}_{2}(\%$, normal reference: $95-100 \%)$ & 80.6 & 90.6 & 85 & 99.6 & 95.9 & 98 \\
\hline
\end{tabular}



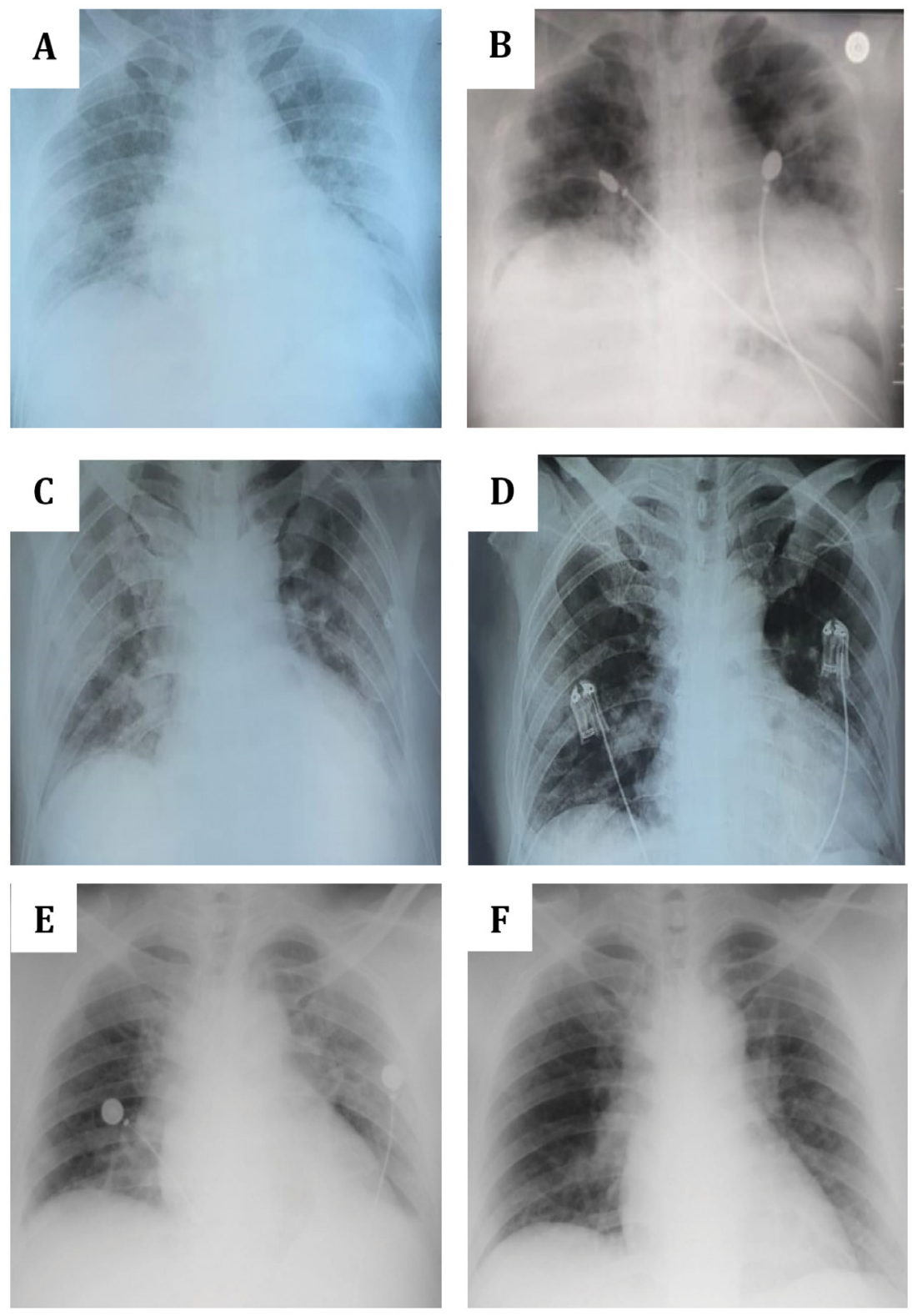

Figure 1. Chest X-ray of the three patients. (A and B) Patient 1. (A) August 29 (a day post onset of illness (dpoi), showing bronchopneumonia with bilateral ground glass opacities (GGOs) and cardiomegaly; (B) September 10 (11 dpoi), showing the absorption of bilateral GGOs with no bronchopneumonia and cardiomegaly. (C and D) Patient 2. (C) November 19 (3 dpoi), showing cardiomegaly with lung edema, bilateral GGOs aorta elongation and aorta atherosclerosis; (D) November 22 (6 dpoi), showing improvement with minimum infiltrate on pulmonalis dextra and sinistra. (E and D) Patient 3. (C) December 23 (7 dpoi), showing worsened bilateral GGOs with cardiomegaly and aortic atherosclerosis; (F) December 28 (12 dpoi), showing decreased bilateral GGOs, cardiomegaly and aortic elongation.

22, chest X-ray showed improvement with minimum infiltrate on pulmonalis dextra and sinistra (Figure 1). On November 23, oxygen saturation was normal $(95.9 \%)$, with normal $\mathrm{PCO}_{2}$ $(36.1 \mathrm{mmHg})$ and $\mathrm{PO}_{2}(71.5 \mathrm{mmHg})$. Laboratory studies showed increased neutrophil count $(85 \%)$ with normal monocyte count $(6 \%)$ and decreased lymphocyte count $(9 \%)$. D-dimer was decreased $(660 \mathrm{ng} / \mathrm{mL})$. Blood chemistries revealed decreased fasting plasma glucose $(277 \mathrm{mg} / \mathrm{dL})$ and CRP $(5.12 \mathrm{mg} / \mathrm{dL}$ (Table 3). On December 5, the patient has no cough, dyspnea, chest pain and fatigue. Examination showed that $\mathrm{SO}_{2}$ was $99.2 \%$. He was discharged from ICU and mobilized into rehabilitation room for physical activity recovery. On December 28, laboratory studies showed normal neutrophil (57\%) and lymphocyte count $(27 \%)$ with increased monocyte count $(11 \%)$. 


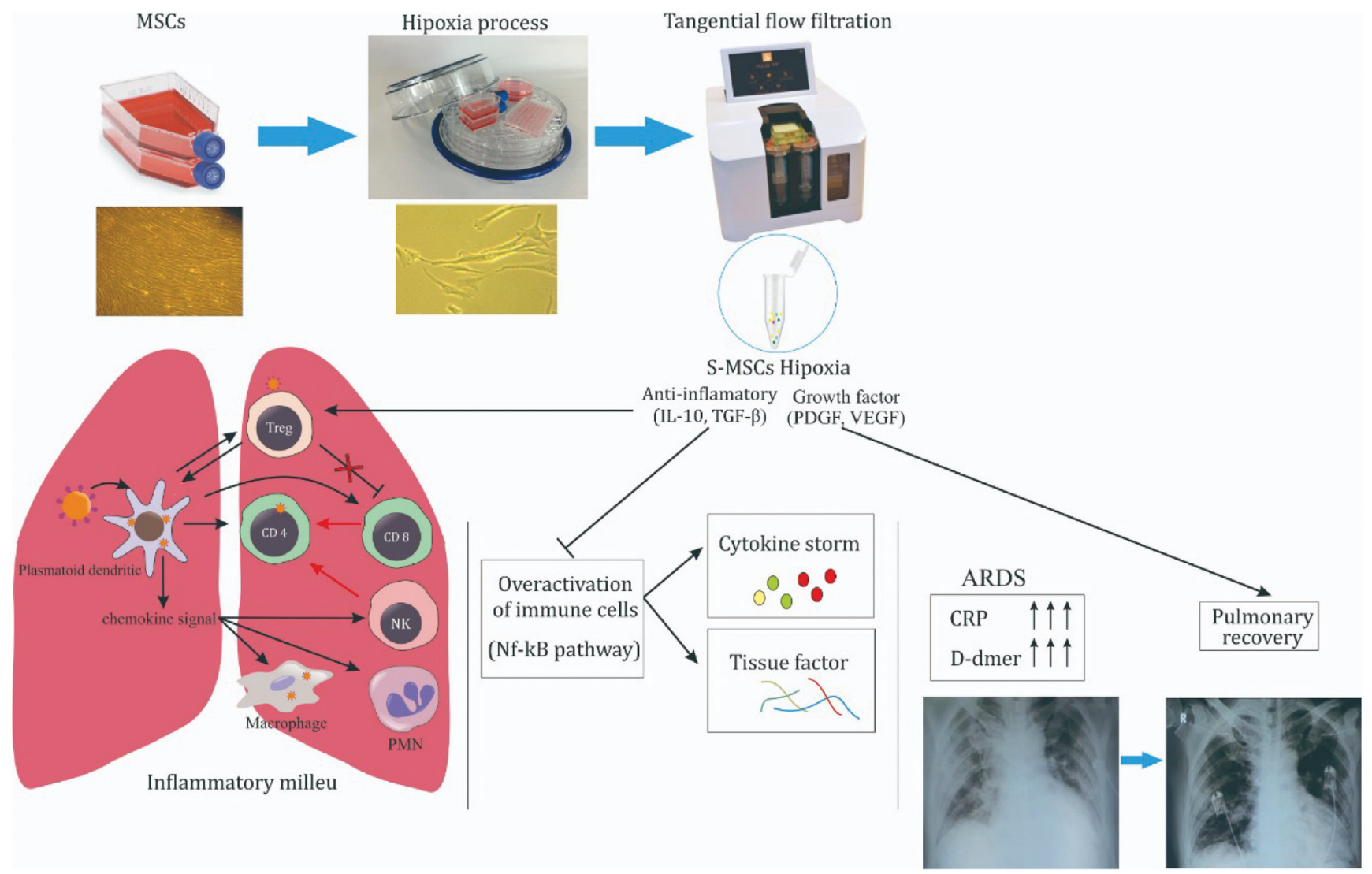

Figure 2. Schematic of cytokine storm on severe COVID-19 treated by S-MSCs. MSCS were incubated in 5\% $\mathrm{O}_{2}$ hypoxia condition and S-MSCs was isolated from the culture medium using TFF technique ${ }^{12}$. S-MSCs contain soluble molecules, including IL-10, TGF- $\beta$, PDGF and VEGF. IL-10 and TGF- $\beta$ inhibit NF-kB pathways activation of overactivated immune cells leading to cytokine storm inhibition, characterized by the decreased level of CRP and D-dimer. Under controlled inflammatory milieu, VEGF and PDGF promote the improvement of bilateral GGOs marked by pulmonary recovery.

Chest X-ray showed normal cardiac physiology and no infiltrate or nodule in both pulmonalis.

\section{Case no. 3}

A 72-year-old Indonesian male with mild hypertension, liver failure, long-term sequelae of stroke and thalassemia minor was diagnosed with COVID-19 on December 16, 2020 and admitted to Bhayangkara Hospital, Makassar, Indonesia with abdominal pain, diarrhea, anosmia, cough and sore throat in the last three days (Table 1). The examination showed a temperature of $37.3^{\circ} \mathrm{C}$, pulse of $82 / \mathrm{min}$, respiratory rate of $24 / \mathrm{min}$, blood pressure of $140 / 90 \mathrm{mmHg}$, and $\mathrm{SO}_{2}$ of $97 \%$. Laboratory studies showed a decreased WBC count $\left(3.1 \times 10^{9} / \mathrm{L}\right)$, with normal neutrophil count (53.4\%), lymphocyte count (26.8\%) and increased monocyte count (18.8\%). Chest X-ray showed bilateral GGOs. On December 23, the patient's dyspnea worsened and he was admitted to the ICU and treated with standard treatment (Table 2). Blood gas analysis revealed that oxygen saturation was decreased $(85 \%)$ with decreased $\mathrm{PCO}_{2}$ $(30 \mathrm{mmHg}), \mathrm{PO}_{2}(49 \mathrm{mmHg})$ and $\mathrm{HCO}_{3}^{-}(19 \mathrm{mmol} / \mathrm{L})$. Laboratory tests showed an increased neutrophil count (72.9\%), monocyte count $(14.9 \%)$ and decreased lymphocyte count $(11.7 \%)$.
D-dimer was increased (235 $\mathrm{ng} / \mathrm{mL})$ and blood chemistries revealed elevations in CRP $(118 \mathrm{mg} / \mathrm{L}$ (Table 3$)$. Chest X-ray showed worsened bilateral GGOs with cardiomegaly and aortic atherosclerosis (Figure 1).

On December 24-26, the patient was treated with $1 \mathrm{~mL}$ S-MSCs six times every $12 \mathrm{~h}$ via deltoid intramuscular injection in addition to other standard treatment (Table 2). The day after the first S-MSC injection, oxygen saturation increased (98\%). The examination showed a temperature of $37^{\circ} \mathrm{C}$, pulse of $90 / \mathrm{min}$, respiratory rate of $28 / \mathrm{min}$ and blood pressure of 120/80 mmHg. On December 28, examination showed a temperature of $37^{\circ} \mathrm{C}$, pulse of $80 / \mathrm{min}$, respiratory rate of $24 / \mathrm{min}$ and blood pressure of $120 / 80 \mathrm{mmHg}$. Oxygen saturation was normal $(98 \%)$. Laboratory studies showed normal neutrophil count (78.3\%) monocyte count $(7.2 \%)$ and lymphocyte count $(25.8 \%)$. D-dimer was decreased $(86.9 \mathrm{ng} / \mathrm{mL})$. Blood chemistries revealed decreased CRP (8.5 mg/dL (Table 2). Chest X-ray showed decreased bilateral GGOs, cardiomegaly and aortic elongation (Figure 1). On December 30, the patient has no abdominal pain, diarrhea, anosmia, cough and sore throat. The examination showed that $\mathrm{SO} 2$ was $99 \%$. He was discharged from ICU 
and mobilized into rehabilitation room for standard physical activity recovery. On January 6 , the patient was negative for COVID-19.

\section{Discussion}

Severe pneumonia COVID-19 is characterized by rapid viral infection, excessive inflammatory cell infiltration and robust cytokine storm associated with an increase of D-dimer and CRP levels, resulting in acute respiratory distress syndrome $(\mathrm{ARDS})^{13}$. A previous study reported that the cytokine storm of COVID-19 was associated with an increase of several proinflammatory cytokines, including TNF- $\alpha$, IL-1, IL-6, IL-17A and granulocyte macrophage colony-stimulating factor (GM-CSF) in the plasma. In line with this phenomenon, lymphocyte count in severe COVID-19 patients' peripheral blood was decreased ${ }^{14,15}$. Another study also revealed that lymphocyte count in severe COVID-19 patients was reduced due to overactivated immune cells, known as macrophage activated syndrome (MAS). The MAS potentially promotes the excessive cytokines storm characterized by the increase of CRP and D-dimer level leading to bilateral GGOs ${ }^{16}$. S-MSCs contain several anti-inflammatory cytokines, including IL-10 and TGF- $\beta$, to control the overactivated immunity and hamper the storm's excessive cytokines. In addition, S-MSCs also have several growth factors, such as VEGF and PDGF, that could accelerate lung injury improvement in COVID-19 patient ${ }^{8,11}$.

This is the first report that suggests the feasibility of S-MSC therapy of three severe COVID-19 patients in Indonesia. All patients showed bilateral GGOs on chest X-ray before treatment. The hematologic findings showed elevated D-dimer and CRP level in addition to lymphocytopenia and decrease of $\mathrm{SO}_{2}$ and $\mathrm{PO}_{2}$. These patients received several doses of S-MSCs ( $1 \mathrm{~mL} /$ dose $) / 12 \mathrm{~h}$ with molecular weight cut-off combination of $10-50 \mathrm{kDa}(50 \%), 50-100 \mathrm{kDa}(25 \%)$ and $100-300 \mathrm{kDa}(25 \%)$, which results in favorable outcomes. This study showed that between three and six doses of S-MSCs were well tolerated by the patients. The clinical symptoms were significantly improved with patchy GGO improvement, associated with the decrease of D-dimer and CRP level and increase of $\mathrm{SO}_{2}$ and $\mathrm{PO}_{2}$. From our observation, we would suggest that six doses of S-MSCs performed the most optimal treatment in the COVID-19 patients. These results suggest that the immune system's excessive inflammation and overactivation were alleviated by anti-inflammatory cytokines contained in S-MSCs, while the high level of growth factors in S-MSCs could also accelerate the improvement of GGOs. Based on our preliminary results, S-MSC therapy could be a promising and safe rescue option to treat severe COVID-19 patients.

The first key factor associated with effective S-MSC therapy is the controlled immune system overactivation resulting in the alleviated cytokines storm characterized by the decrease in CRP and D-dimer levels. In our observations, the level of CRP and D-dimer was decreased in all patients treated with S-MSCs. This data suggest that S-MSCs could effectively control the overactivated immune cells. A previous study reported that S-MSCs could control proinflammatory immune cells due to their anti-inflammatory cytokines, such as IL-10 and TGF- $\beta^{11,17}$. IL-10 could hamper the inflammatory cells' activity by activating tyrosine kinase-2 and Janus tyrosine kinase 1 (JAK1) and inhibiting NF-kB pathways leading to the decreased expression of proinflammatory cytokines such as TNF- $\alpha$, IL-1, IL-6 and IL-17A ${ }^{9,18}$. On the other hand, TGF- $\beta$ could activate the regulatory subset of $\mathrm{T}$ lymphocyte (Treg) by initiating the FoxP3 expression, resulting in suppressing overactivated immune cells ${ }^{19}$ (Figure 2).

Another key factor associated with the efficacy of S-MSCs treatment is the acceleration of lung injury improvement characterized by the improvement pulmonary radiological results, decrease of CRP and D-dimer level resulting in the controlled inflammation leading to normal pulmonary function marked by normal $\mathrm{SO}_{2}$. In our patients, decreased CRP and D-dimer was associated with the improvement of patchy GGOs and normal $\mathrm{SO}_{2}$ in all patients treated with S-MSCs. These data suggest that along with the controlled immune overactivation, the growth factors contained in S-MSCs could rapidly improve lung regeneration post excessive cytokine storm exposure. A previous study revealed that S-MSCs could accelerate wound healing due to their growth factors, particularly VEGF and $\mathrm{PDGF}^{20}$. VEGF and PDGF could accelerate the repair of leaky pulmonary blood vessels and accelerate lung injury improvement through the MEK and Akt pathway resulting in the acceleration of angiogenesis and reduced pulmonary infiltrate characterized by decreased bilateral GGOs ${ }^{21,22}$ (Figure 2).

In our patients, no severe adverse effects were observed. However, one limitation of our report is that the dynamic changes of cytokine and growth factors during treatment were not investigated. Nevertheless, the preliminary result seem promising.

In conclusion, we report that S-MSC therapy shows a potential therapeutic effect and low risk in severe COVID-19 patient treatment. We observed that between three and six doses of S-MSCs, with weight cut-off combination of $10-50 \mathrm{kDa}$ (50\%), 50-100 kDa (25\%) and $100-300 \mathrm{kDa}(25 \%)$, rapidly controlled the excessive cytokine storm in our patients and improved lung injury. Six doses showed optimum outcome. The treatment time point and the clear clinical advantages of S-MSCs therapy need to be further investigated in randomized clinical studies.

\section{Consent}

Written informed consent for publication of this case report, along with any associated images, was obtained from all three patients.

Written informed consent was also obtained from the patients to undergo treatment using the novel treatment.

\section{Data availability}

All data underlying the results are available as part of the article and no additional source data are required. 
Acknowledgements

We would like to thank Gatot Soebroto Army Hospital,

Dr. Esnawan Antariksa Air Force Hospital Jakarta and
Bhayangkara Hospital, Makassar, Indonesia for supporting the medical data collection. We would also thank to Stem Cell and Cancer Research (SCCR) laboratory for supporting this study.
1. Munster VJ, Koopmans M, van Doremalen N, et al.: A Novel Coronavirus Emerging in China - Key Questions for Impact Assessment. N Engl J Med. 2020; 382(8): 692-694.

PubMed Abstract | Publisher Full Text

2. Johns Hopkins University \& Medicine: Coronavirus Resource Center. 2021; Accessed January 22,2021.

Reference Source

3. Dubert $M$, Visseaux $B$, Isernia $V$, et al.: Case report study of the first five COVID-19 patients treated with remdesivir in France. Int J Infect Dis. 2020; 98: 290-293.

PubMed Abstract | Publisher Full Text | Free Full Text

4. Agarwal A, Mukherjee A, Kumar G, et al.: Convalescent plasma in the management of moderate covid-19 in adults in India: open label phase II multicentre randomised controlled trial (PLACID Trial). BMJ. 2020; 371: m3939.

PubMed Abstract | Publisher Full Text | Free Full Text

5. Johnson BS, Laloraya M: A cytokine super cyclone in COVID-19 patients with risk factors: the therapeutic potential of BCG immunization. Cytokine Growth Factor Rev, 2020; 54: 32-42.

PubMed Abstract | Publisher Full Text | Free Full Text

6. Huang C, Wang Y, Li X, et al.: Clinical features of patients infected with 2019 novel coronavirus in Wuhan, China. Lancet. 2020; 395(10223): 497-506. PubMed Abstract | Publisher Full Text | Free Full Text

7. Yang $X, Y u Y, X u$ J, et al.: Clinical course and outcomes of critically ill patients with SARS-CoV-2 pneumonia in Wuhan, China: a single-centered, retrospective, observational study. Lancet Respir Med. 2020; 8(5): 475-481. PubMed Abstract | Publisher Full Text | Free Full Text

8. Eleuteri S, Fierabracci A: Insights into the Secretome of Mesenchymal Stem Cells and Its Potential Applications. Int J Mol Sci. 2019; 20(18): 4597. PubMed Abstract | Publisher Full Text | Free Full Text

9. Muhar AM, Putra A, Warli SM, et al.: Hypoxia-Mesenchymal Stem Cells Inhibit Intra-Peritoneal Adhesions Formation by Upregulation of the IL-10 Expression. Open Access Maced J Med Sci. 2019; 7(23): 3937-3943. PubMed Abstract | Free Full Text

10. Can $\mathrm{A}$, Coskun $\mathrm{H}$ : The rationale of using mesenchymal stem cells in patients with COVID-19-related acute respiratory distress syndrome: What to expect. Stem Cells Trans/ Med. 2020; 9(11): 1287-1302. PubMed Abstract | Publisher Full Text | Free Full Text

11. Chen $\mathrm{L}, \mathrm{Xu} \mathrm{Y}, \mathrm{Zhao}$ J, et al:: Conditioned medium from hypoxic bone marrowderived mesenchymal stem cells enhances wound healing in mice. PLOS One. 2014; 9(4): e96161.

PubMed Abstract | Publisher Full Text | Free Full Text
12. Haraszti RA, Miller R, Stoppato M, et al.: Exosomes Produced from 3D Cultures of MSCs by Tangential Flow Filtration Show Higher Yield and Improved Activity. Mol Ther. 2018; 26(12): 2838-2847.

PubMed Abstract | Publisher Full Text | Free Full Text

13. Channappanavar R, Perlman S: Pathogenic human coronavirus infections: causes and consequences of cytokine storm and immunopathology. Semin Immunopathol. 2017; 39(5): 529-539. PubMed Abstract | Publisher Full Text | Free Full Text

14. Chen N, Zhou M, Dong $X$, et al:: Epidemiological and clinical characteristics of 99 cases of 2019 novel coronavirus pneumonia in Wuhan, China: a descriptive study. Lancet. 2020; 395(10223): 507-513. PubMed Abstract | Publisher Full Text | Free Full Text

15. Sun HB, Zhang YM, Huang LG, et al.: The changes of the peripheral CD4+ lymphocytes and inflammatory cytokines in Patients with COVID-19. PLOS One. 2020; 15(9): e0239532.

PubMed Abstract | Publisher Full Text | Free Full Text

16. Otsuka R, Seino KI: Macrophage activation syndrome and COVID-19. Inflamm Regen. 2020; 40: 19

PubMed Abstract | Publisher Full Text | Free Full Text

17. Putra A, Ridwan FB, Putridewi AI, et al:: The Role of TNF- $a$ induced MSCs on Suppressive Inflammation by Increasing TGF- $\beta$ and IL-10. Open Access Maced J Med Sci. 2018; 6(10): 1779-1783. PubMed Abstract | Free Full Text

18. Darlan DM, Munir D, Putra A, et al.: MSCs-released TGF $\beta 1$ generate CD4 + CD25 + Foxp3 ${ }^{+}$in T-reg cells of human SLE PBMC. J Formos Med Assoc. 2021; 120(1 Pt 3): 602-608

PubMed Abstract | Publisher Full Text

19. Ahangar P, Mills SJ, Cowin AJ: Mesenchymal Stem Cell Secretome as an Emerging Cell-Free Alternative for Improving Wound Repair. Int J Mol Sci. 2020; 21(19): 7038.

PubMed Abstract | Publisher Full Text | Free Full Text

20. Fournier NM, Lee B, Banasr M, et al.: Vascular endothelial growth factor regulates adult hippocampal cell proliferation through MEK/ERK- and PI3K/Akt-dependent signaling. Neuropharmacology. 2012; 63(4): 642-52. PubMed Abstract | Publisher Full Text | Free Full Text

21. Fang J, Huang $X, \operatorname{Han} X$, et al.: Endothelial progenitor cells promote viability and nerve regenerative ability of mesenchymal stem cells through PDGFBB/PDGFR- $\beta$ signaling. Aging (Albany NY). 2020; 12(1): 106-121. PubMed Abstract | Publisher Full Text | Free Full Text

22. Dhingra S, Sharma AK, Arora RC, et al.: IL-10 attenuates TNF-alpha-induced NF kappaB pathway activation and cardiomyocyte apoptosis. Cardiovasc Res. 2009; 82(1): 59-66.

PubMed Abstract | Publisher Full Text 


\section{Open Peer Review}

\section{Current Peer Review Status:}

\section{Version 1}

Reviewer Report 05 July 2021

https://doi.org/10.5256/f1000research.54326.r87539

(C) 2021 Moll G. This is an open access peer review report distributed under the terms of the Creative Commons Attribution License, which permits unrestricted use, distribution, and reproduction in any medium, provided the original work is properly cited.

\section{Guido Moll}

BIH Center for Regenerative Therapies (BCRT) and Berlin-Brandenburg School of Regenerative Therapies (BSRT), Berlin Institute of Health, Charité - University Medicine Berlin, Berlin, Germany

In this Case Study, Putra et al. report the experimental treatment of three patients suffering from severe COVID-19 with hypoxia-conditioned mesenchymal stromal cell (MSC)-derived secretome (SMSC) prepared by tangential flow filtration (TFF), to prepare the highly concentrated/enriched MSC secretome for clinical application. In their introduction and discussion, the authors identify among others the COVID-19 cytokine storm and concomitant severe lung and tissue damage, as targets of MSC therapy, anticipating that MSC therapy may exert pleiotropic beneficial effects.

The Case Study was conducted at Bethesda Hospital in Yogyakarta, Indonesia (With Local Health Research Committee approval number No.91/KEPK-RSB/V1/20), with written informed consent for the treatment with S-MSCs obtained from each patient prior to treatment. All patients received standard treatment for severe COVID-19, with on-top adjunct treatment with S-MSCs. This is a Case Report of three patients, who were all treated in exploratory fashion with different doses of S-MSCs, and there is no control group or control patients reported in the study.

The S-MSC was prepared by TFF to enrich bioactive factors secreted by the MSCs into $1 \mathrm{ml}$ therapeutic doses. The S-MSCs were applied in each of the three patients six times every 12 hours via deltoid intramuscular injection. Molecular weight cut-off combination of 10-50 kDa 50\%, 50-100 $\mathrm{kDa} 25 \%$, and $100-300 \mathrm{kDa} 25 \%$ were used. The production method of S-MSC is outlined in reference number 12: Haraszti et al. ${ }^{1}$ Exosomes Produced from 3D-cultures of MSCs by Tangential Flow Filtration Show higher Yield and Improved Activity published in Molecular Therapy in 2018.

The authors report:

In Table 1) Clinical Characteristics of Patients Receiving S-MSC: Patient Sex, Age, Clinical Classification (Severe COVID-19), Principal Symptoms, Respective Comorbidities (e.g. Hypertension, T2D, Liver Failure, Stroke, Thalassemia);

In Table 2) Standard Treatment Received by the Three Patients: Drugs Administered 
(Antiviral, Antibiotic, Antifungal, and Corticosteroid Treatment) and Oxygen Support (Before / After S-MSC Therapy);

In Table 3) Comparison of Laboratory Parameters Before and After S-MSC Treatment (CRP, D-Dimer, Lymphocytes, SO2); and in Figure 1 and 2) Chest X-ray's of the Three Patients and a Schematic Study Overview, respectively.

Given the standard of care treatment, that there was no control group, and that this was an open label Case Study, the key findings of this report are as follows (although any of these findings could also be a result of the standard treatment):

1. CRP was strongly log-scale reduced after S-MSC treatment (from 62, 160, 118 to 0.4, 5.1, and 8.5),

2. D-dimer was reduced around 2-fold on average $(1540,880,235$ to $384,660,87)$,

3. Lymphocyte counts normalized/2-fold increased on average $(15,10,12$ to $20,27,26)$,

4. SO2 increased/improved $(89.6,90.6,85$ to $99.6,95.9,98)$ together with PO2, and 5) Chest xrays mainly indicated that lung pathology and cardiomegaly improved (reduction of bilateral ground glass opacities and cardiomegaly).

In their introduction and discussion, the authors briefly outline the study hypothesis and why MSC / S-MSC treatment may be beneficial and relate this to the improved functional parameters in their Case Study, and these findings are in line with other clinical reports on MSC treatment of COVID19. So it stands to reason that hypoxia conditioned S-MSC (concentrated soluble fraction of MSC media) is first of all safe, and second may be just as efficient as cellular MSCs in treating COVID-19. However, given the lack of a control group, and open-label treatment of these three patients the findings should be interpreted with caution. Interestingly, not only inflammation and lung parameters improved, but also D-dimer levels, as typically observed in the follow-up of successfully treated patients, see "Viscoelastic Testing Reveals Normalization of the Coagulation Profile 12 Weeks After Severe COVID-19" 2 published in Scientific Reports in 2021.

The authors recognized COVID-19 coagulopathy as a challenge for MSC therapy, as reported earlier in "MSC Therapies for COVID19: Importance of Patient Coagulopathy, Thromboprophylaxis, Cell Product Quality and Mode of Delivery for Treatment Safety and Efficacy" ${ }^{3}$ published in Frontiers in Immunology 2020 and "Intravascular MSC Therapy Product Diversification: Time for New Clinical Guidelines" 4 published in Trends in Molecular Medicine 2019). Another crucial point is the appropriate timing and dosing and mode of application of MSC therapy in COVID-19, "Mesenchymal Stromal Cell Therapy for Coronavirus Disease 2019: Which? When? And How Much?" 5 published in Cytotherapy 2021.

The authors indicate their approach as a rescue treatment for patients progressed to severe COVID-19 stage (often presenting with pronounced coagulopathy). Here, the application of cellular secretome instead of the actual cellular MSC products may be somewhat superior/safer given the expression of varying levels of highly procoagulant Tissue Factor (TF/CD142) on MSCs (See PMID's $32574263^{3}$ and $30711482^{4}$. In this context, another key advantage of this study may be that the S-MSC was applied via deltoid intramuscular injection. 
Future studies should also put more emphasis on well-controlled dose escalation, pharmacokinetics and pharmacodynamics, as well as biodistribution of the product with tight monitoring of coagulation/complement markers and other safety parameters, adjunct with deeper monitoring of a broader panel of biomarkers of response (e.g. systemic and potentially tissue cytokine profiling in blood and BAL as well as longitudinal monitoring of immune cell subsets in the periphery and local tissue BAL). Another important point is the timing of the treatment relative to the diseases stage (e.g. newly diagnosed vs. progressed patients, identify optimal treatment window). Presumably, S-MSC is an allogeneic off-the-shelf product, thus aspects of alloimunization should be studied in more detailed (humoral and cellular alloimunization). Another important issue is the GMP-compliant production of S-MSC for use in human patients.

\section{References}

1. Haraszti R, Miller R, Stoppato M, Sere $Y$, et al.: Exosomes Produced from 3D Cultures of MSCs by Tangential Flow Filtration Show Higher Yield and Improved Activity. Molecular Therapy. 2018; 26

(12): 2838-2847 Publisher Full Text

2. Magomedov A, Zickler D, Karaivanov S, Kurreck A, et al.: Viscoelastic testing reveals normalization of the coagulation profile 12 weeks after severe COVID-19. Scientific Reports. 2021; 11 (1). Publisher Full Text

3. Moll G, Drzeniek N, Kamhieh-Milz J, Geissler S, et al.: MSC Therapies for COVID-19: Importance of Patient Coagulopathy, Thromboprophylaxis, Cell Product Quality and Mode of Delivery for Treatment Safety and Efficacy.Front Immunol. 2020; 11: 1091 PubMed Abstract | Publisher Full Text 4. Moll G, Ankrum JA, Kamhieh-Milz J, Bieback K, et al.: Intravascular Mesenchymal Stromal/Stem Cell Therapy Product Diversification: Time for New Clinical Guidelines.Trends Mol Med. 25 (2): 149163 PubMed Abstract | Publisher Full Text

5. Shahani P, Datta I: Mesenchymal stromal cell therapy for coronavirus disease 2019: which? when? and how much?. Cytotherapy. 2021. PubMed Abstract | Publisher Full Text

Is the background of the cases' history and progression described in sufficient detail? Yes

Are enough details provided of any physical examination and diagnostic tests, treatment given and outcomes?

Yes

Is sufficient discussion included of the importance of the findings and their relevance to future understanding of disease processes, diagnosis or treatment?

Yes

Is the conclusion balanced and justified on the basis of the findings?

Yes

Competing Interests: No competing interests were disclosed.

Reviewer Expertise: Immunology; Cardiovascular System; COVID-19; Stem Cell Therapy; Mesenchymal Stromal Cells (MSCs)

I confirm that I have read this submission and believe that I have an appropriate level of 
expertise to confirm that it is of an acceptable scientific standard.

Author Response 17 Jul 2021

Agung Putra, Universitas Islam Sultan Agung (Unissula), Semarang, Indonesia

Dear Reviewer

Thank you for giving us the opportunity to submit a revised of our manuscripts "Case series of the first three severe COVID-19 patients treated with the secretome of hypoxiamesenchymal stem cells in Indonesia". We appreciate the time and effort that reviewers dedicated to providing feedback on our manuscript and are grateful for the insightful comments on and valuable improvements to our paper. We have incorporated most of the suggestions made by the reviewers. Those changes are highlighted within the manuscript and extended data. Please see below, in bold, for a point-by-point response to the reviewers' comments and concerns. All page numbers refer to the revised manuscript file with tracked changes (yellow highlight).

This is a Case Report of three patients, who were all treated in exploratory fashion with different doses of S-MSCs, and there are no control group or control patients reported in the study.

Author response: Thank you for pointing this out. The reviewer is correct that we are reporting the findings of a case report study, and we do not utilize a control group to compare the relevance of the results.

So, it stands to reason that hypoxia conditioned S-MSC (concentrated soluble fraction of MSC media) is first of all safe,

Author response: We confirm the reviewer's statement if certainly what was emphasized at the outset was the safety of the use of S-MSCs. We believe that S-MSC is safe because it has undergone a sterile ultrafiltration process using a TFF strategy of up to $10 \mathrm{kDA}$ in size, so contamination is not possible. Future studies of S-MSCs will lead the safety parameters.

Second maybe just as efficient as cellular MSCs in treating COVID-19.

Author Response: Regarding the efficacy of S-MSCs to treat the severe condition of COVID-19, we suggest that the S-MSCs is more efficient than cellular MSCs. This is due to the pulmonary intravascular coagulopathy (PIC) that present in severe COVID-19 patients could blockage the direction of cellular MSCs to homing to injured pulmonary. We use S-MSCs molecules under 300 kDA which makes it possible to get past the blockages due to PIC to modulate the inflammatory condition and enhance pulmonary regeneration.

Interestingly, not only inflammation and lung parameters improved, but also D-dimer levels, as typically observed in the follow-up of successfully treated patients

Author response: We suggest that the possibility of S-MSCs to improve D-dimer levels, besides lung parameters is the controlled immune system's excessive inflammation and overactivation and the improvement of the lung caused by anti-inflammatory 
cytokines and growth factors contained in S-MSCs which possible to pass the PIC blockages.

Future studies should also put more emphasis on well-controlled dose-escalation, pharmacokinetics, and pharmacodynamics, as well as biodistribution of the product with tight monitoring of coagulation/complement markers and other safety parameters, adjunct with deeper monitoring of a broader panel of biomarkers of response (e.g. systemic and potentially tissue cytokine profiling in blood and BAL as well as longitudinal monitoring of immune cell subsets in the periphery and local tissue BAL). Another important point is the timing of the treatment relative to the disease's stage (e.g. newly diagnosed vs. progressed patients, identify optimal treatment window).

Author response: We agree that this is a potential limitation of the study. In our future study, we will analyze the pharmacokinetics, pharmacodynamics, and biodistribution of the secretome. Furthermore, in the prospective study, we will also evaluate the parameter related to cytokine profiling in blood and BAL and monitoring of immune cell subsets in the periphery and local tissue BAL. We also agree that another potential limitation is no information about the disease stage of patients receiving secretome MSCs treatment. In the future study, it is planned to make several groups of patients who describe the different disease stages to determine the optimal treatment window.

S-MSC is an allogeneic off-the-shelf product, thus aspects of alloimmunization should be studied in more detail (humoral and cellular alloimmunization). Another important issue is the GMP-compliant production of S-MSC for use in human patients

Author response: Thank you for pointing this out. We agree that this is an important consideration, we have added the MSCs characterization in extended data, figure S1. Based on this data, the expression CD34, CD45, CD11b, CD19, and HLA-DR are represented as Lin $<2 \%$. It can be concluded that the possibility of an allergic reaction is quite limited. Although the potential of allergic reactions is limited, further studies need to be carried out.

Competing Interests: Authors declare that they have no conflict of interest.

Reviewer Report 05 July 2021

https://doi.org/10.5256/f1000research.54326.r85411

(C) 2021 Ramasamy R. This is an open access peer review report distributed under the terms of the Creative Commons Attribution License, which permits unrestricted use, distribution, and reproduction in any medium, provided the original work is properly cited.

\section{Rajesh Ramasamy}

Department of Pathology, Universiti Putra Malaysia, Selangor, Malaysia 
The authors have tested the usefulness of mesenchymal stem/stromal cells-derived filtered supernatant to treat severe ARS due to COVID-19. The outcomes of the intervention were measured through the parameter of CRP, D-Dimer, and improvement of patients' clinical conditions. The tested treatment indeed showing a range of positive outcomes on the patients. The following technical queries require clarifications:

1. Provided the supplementary laboratory data on the characterisation of MSC.

2. Include the details of the hypoxic conditions that catered to the MSC.

3. What would be the rationale for selecting various percentages and molecular weight for filtering the supernatant?

4. Any profiling of cytokines or growth factors had been conducted prior to injecting the secretome into the patients?

The discussion should be made with achieved results rather than the anticipated immunosuppressive action of MSCs. There is no standardisation of MSC secretome. It could be possible that the exosome and microRNA in the secretome mediate the reparative function of MSCs through variable actions that include tissue repair.

Is the background of the cases' history and progression described in sufficient detail? Yes

Are enough details provided of any physical examination and diagnostic tests, treatment given and outcomes?

Partly

Is sufficient discussion included of the importance of the findings and their relevance to future understanding of disease processes, diagnosis or treatment?

Yes

Is the conclusion balanced and justified on the basis of the findings?

Partly

Competing Interests: No competing interests were disclosed.

Reviewer Expertise: Mesenchymal Stem Cell and Immunomodulation

I confirm that I have read this submission and believe that I have an appropriate level of expertise to confirm that it is of an acceptable scientific standard, however I have significant reservations, as outlined above.

Author Response 17 Jul 2021

Agung Putra, Universitas Islam Sultan Agung (Unissula), Semarang, Indonesia

Dear Reviewer 
Thank you for giving us the opportunity to submit a revised of our manuscripts "Case series of the first three severe COVID-19 patients treated with the secretome of hypoxiamesenchymal stem cells in Indonesia". We appreciate the time and effort that reviewers dedicated to providing feedback on our manuscript and are grateful for the insightful comments on and valuable improvements to our paper. We have incorporated most of the suggestions made by the reviewers. Those changes are highlighted within the manuscript and extended data. Please see below, in bold, for a point-by-point response to the reviewers' comments and concerns. All page numbers refer to the revised manuscript file with tracked changes (yellow highlight).

Provided supplementary laboratory data on the characterization of MSC.

Author response: Thank you for your suggestion. We have added the suggestion content on extended data, figure S1.

Include the details of the hypoxic conditions that catered to the MSCs.

Author response: Thank you for this suggestion. We have added the details of hypoxic conditions on the discussion section that mark as the yellow highlight.

What would be the rationale for selecting various percentages and molecular weight for filtering the supernatant?

Author response: We selected the 10-50 and 50-100 kDa molecular weight filtering to obtain the desired cytokines and growth factors, such as IL-10, TGF- $\beta$, VEGF, and PDGF. We also use $25 \%$ S-MSCs with 100-300 kDA categories to obtain the miRNA and exosome. However, we do not analyze the exosome and miRNA contained in S-MSCs. Further studies need to be carried out.

Any profiling of cytokines or growth factors had been conducted prior to injecting the secretome into the patients?

Author response: We have evaluated the cytokine and growth factor profiles before injecting secretome MSCs into patients. We are confirming that the quality of the secretome MSCs administered is consistent on all three patients (See extended data, table $\mathbf{S 1}$ for more details).

The discussion should be made with achieved results rather than the anticipated immunosuppressive action of MSCs. There is no standardisation of MSC secretome. It could be possible that the exosome and microRNA in the secretome mediate the reparative function of MSCs through variable actions that include tissue repair. Author response: Thank you for your suggestion. Accordingly, throughout the manuscript, we have revised and discussed the results in the discussion section such as:

"The clinical symptoms were significantly improved with patchy GGO improvement, associated with the decrease of D-dimer and CRP level and increase of SO 2 and PO 2. From our observation, we would suggest that six doses of S-MSCs performed the most optimal treatment in the COVID-19 patients. These results suggest that the immune 
system's excessive inflammation and overactivation were alleviated by antiinflammatory cytokines contained in S-MSCs, while the high level of growth factors in S-MSCs could also accelerate the improvement of GGOs."

"In our observations, the level of CRP and D-dimer was decreased in all patients treated with S-MSCs. This data suggest that S-MSCs could effectively control the overactivated immune cells. A previous study reported that S-MSCs could control proinflammatory immune cells due to their anti-inflammatory cytokines, such as IL-10 and TGF- $\beta$ 11, $17 . "$

We also agree with the reviewer's assessment that there is no standardization of secretome MSCs. Secretome MSCs contain exosome and soluble molecule active. This is a potential limitation of the study because we have not standardized the secretome MSCs. Therefore, further studies of secretome MSCs standardization need to be carried out.

Competing Interests: Authors declare that they have no conflict of interest.

The benefits of publishing with F1000Research:

- Your article is published within days, with no editorial bias

- You can publish traditional articles, null/negative results, case reports, data notes and more

- The peer review process is transparent and collaborative

- Your article is indexed in PubMed after passing peer review

- Dedicated customer support at every stage

For pre-submission enquiries, contact research@f1000.com 